\title{
Articles
}

\section{Acute effects of glucose and insulin on vascular endothelium}

\author{
D. Taubert ${ }^{1}$ A. Rosenkranz ${ }^{1}$ - R. Berkels ${ }^{1}$ R. Roesen ${ }^{1}$ E. Schömig ${ }^{1}$ \\ ${ }^{1}$ Department of Pharmacology, Medical Hospital of the University of Cologne, Cologne, Germany
}

\begin{abstract}
Aims/hypothesis. Chronic exposure to high concentrations of glucose has consistently been demonstrated to impair endothelium-dependent, nitric oxide (NO)-mediated vasodilation. In contrast, several clinical investigations have reported that acute exposure to high glucose, alone or in combination with insulin, triggers vasodilation. The aim of this study was to examine whether elevated glucose itself stimulates endothelial NO formation or enhances insulin-mediated endothelial NO release.

Methods. We measured NO release and vessel tone ex vivo in porcine coronary conduit arteries (PCAs). Intracellular $\mathrm{Ca}^{2+}$ was monitored in porcine aortic endothelial cells (PAECs) by fura-2 fluorescence. Expression of the $\mathrm{Na}^{+}$/glucose cotransporter-1 (SGLT-1) was assayed in PAECs and PCA endothelium by RT-PCR. Results. Stimulation of PCAs with D-glucose, but not the osmotic control L-glucose, induced a transient increase in $\mathrm{NO}$ release $\left(\mathrm{EC}_{50} \approx 10 \mathrm{mmol} / \mathrm{l}\right)$, mediated by a rise in
\end{abstract}

intracellular $\mathrm{Ca}^{2+}$ levels due to an influx from the extracellular space. This effect was abolished by inhibitors of the plasmalemmal $\mathrm{Na}^{+} / \mathrm{Ca}^{2+}$ exchanger (dichlorobenzamil) and the SGLT-1 (phlorizin), which was found to be expressed in aortic and coronary endothelium. Alone, D-glucose did not relax PCA, but did augment the effect of insulin on NO release and vasodilation.

Conclusions/interpretation. An increased supply of extracellular D-glucose appears to enhance the activity of the endothelial isoform of nitric oxide synthase by increasing intracellular $\mathrm{Na}^{+}$concentrations via SGLT1 , which in turn stimulates an extracellular $\mathrm{Ca}^{2+}$ influx through the $\mathrm{Na}^{+} / \mathrm{Ca}^{2+}$ exchanger. This mechanism may be responsible for glucose-enhanced, insulin-dependent increases in tissue perfusion (including coronary blood-flow), thus accelerating glucose extraction from the blood circulation to limit the adverse vascular effects of prolonged hyperglycaemia.

Keywords Endothelium $\cdot \mathrm{Na}^{+} / \mathrm{Ca}^{2+}$ exchanger . $\mathrm{Na}^{+} /$glucose cotransporter- 1 - Nitric oxide - Vasodilation
Received: 23 April 2004 / Accepted: 22 July 2004

Published online: 15 December 2004

C) Springer-Verlag 2004

D. Taubert (匹)

Department of Pharmacology,

Medical Hospital of the University of Cologne,

Gleueler Str. 24, 50931 Cologne, Germany

E-mail: dirk.taubert@medizin.uni-koeln.de

Tel.: +49-221-4784196, Fax: +49-221-4785022

Abbreviations: ddAdoPP, 2',5'-dideoxyadenosine-3'diphosphate - eNOS, endothelial isoform of nitric oxide synthase $\cdot$ l-NMMA, $\mathrm{L}-N^{\mathrm{G}}$-monomethyl arginine $\cdot \mathrm{NCX}$, $\mathrm{Na}^{+} / \mathrm{Ca}^{2+}$ exchanger $\cdot \mathrm{NO}$, nitric oxide $\cdot$ PAEC, porcine aortic endothelial cell $\cdot$ PCA, porcine coronary conduit artery $\cdot$ PI3K, phosphatidylinositol 3'-OH kinase - PMCA, plasma membrane $\mathrm{Ca}^{2+}$ ATPase - SERCA, endoplasmic $\mathrm{Ca}^{2+}$ ATPase - SGLT, $\mathrm{Na}^{+}$/glucose cotransporter

\section{Introduction}

Chronic exposure to high glucose has been consistently demonstrated to adversely affect endothelial function and impair nitric oxide (NO)-dependent vasodilation, and has been implicated in diabetes-associated cardiovascular morbidity and mortality $[1,2,3,4]$. Although insulin resistance and glucose intolerance are important risk factors for type 2 diabetes, the majority of subjects who exhibit these alterations do not develop diabetes or persistent endothelial dysfunction [5, 6]. Thus, adaptive responses, particularly maintenance of vascular function, may prevent manifestation of diabetic symptoms. Hyperinsulinaemia and post-prandial hyperglycaemia are the main features of the "prediabetic' state [7, 8]. While the vasodilating effects of insulin are established $[9,10]$, the direct vascular ac- 
tions of short-term hyperglycaemia are largely unknown. Studies investigating the effects of high glucose on macrovascular and microvascular perfusion have yielded conflicting results: some have shown attenuated vasodilation $[11,12,13,14,15,16]$, some have demonstrated enhanced vasodilation $[17,18,19$, 20], whereas others found no changes in vascular tone $[21,22,23]$. The present study was designed to gain deeper insights into the immediate effects of high glucose on endothelial NO formation and vascular tone, and its stimulatory role on the vascular effects of insulin.

\section{Materials and methods}

\section{Chemicals}

Porcine insulin was obtained from Berlin-Chemie (Insulin S, $40 \mathrm{IU} / \mathrm{ml}$; Berlin, Germany). Inorganic salts and solvents were from VWR International (Darmstadt, Germany). Unless otherwise noted, all other reagents were purchased from SigmaAldrich (Deisenhofen, Germany).

\section{Real-time measurement of nitric oxide levels}

Measurements were performed ex vivo using porcine coronary conduit arteries (PCAs), which were freshly dissected at the local abattoir (Fleischversorgung Köln e.V., Cologne, Germany) from the hearts of domestic pigs aged 7-9 months. Luminal NO release was monitored amperometrically in real time by a NO-selective microsensor (ISO-NO-Meter, WPI, Sarasota, Fla., USA) as described previously [24]. Briefly, PCA segments (approximately $2 \mathrm{~cm}$ in length) were opened longitudinally and mounted in organ baths containing $10 \mathrm{ml}$ HEPESmodified Krebs buffer $(140.0 \mathrm{mmol} / \mathrm{l} \mathrm{NaCl}, 5.0 \mathrm{mmol} / \mathrm{l} \mathrm{KCl}$, $2.0 \mathrm{mmol} / 1 \mathrm{CaCl}_{2}, 1.0 \mathrm{mmol} / 1 \mathrm{mgCl}_{2}, 10.0 \mathrm{mmol} / \mathrm{l} \mathrm{HEPES}$ and $5.0 \mathrm{mmol} / \mathrm{l} \mathrm{D}$-glucose, adjusted to $\mathrm{pH} 7.40$ ) at $25^{\circ} \mathrm{C}$. The sensor was positioned under microscopic control at a distance of 200-300 $\mu \mathrm{m}$ above the endothelial surface. All experiments were performed in a non-cumulative fashion by using separate vessels for each concentration of test compound.

\section{Measurement of vascular tone}

The vascular tone of the PCAs was monitored isometrically as described previously [24]. Briefly, PCA rings (length 3-4 mm) were mounted in carbogen-aerated organ chambers containing $10 \mathrm{ml}$ Tyrode solution $\left(161.1 \mathrm{mmol} / \mathrm{l} \mathrm{Na}^{+}, 5.4 \mathrm{mmol} / \mathrm{l} \mathrm{K}^{+}\right.$, $1.8 \mathrm{mmol} / 1 \mathrm{Ca}^{2+}, 1.1 \mathrm{mmol} / 1 \mathrm{mg}^{2+}, 148.0 \mathrm{mmol} / \mathrm{l} \mathrm{Cl}^{-}$, $23.8 \mathrm{mmol} / 1 \mathrm{HCO}_{3}^{-}, 0.4 \mathrm{mmol} / \mathrm{L} \mathrm{H}_{2} \mathrm{PO}_{4}^{-}$and $5.0 \mathrm{mmol} / 1 \mathrm{D}$-glucose) at $37^{\circ} \mathrm{C}$. Single concentrations of test compounds $(50 \mu \mathrm{l})$ were applied to vessels pre-contracted with $\operatorname{PGF}_{2 \alpha}(25 \mu \mathrm{mol} / \mathrm{l})$. Vasodilator responses are expressed as a percentage of the $\mathrm{PGF}_{2 \alpha}$ pre-contraction.

\section{Measurement of intracellular $\mathrm{Ca}^{2+}$ levels}

Culture of porcine aortic endothelial cells. Porcine aortic endothelial cells (PAECs) were enzymatically (dispase, $1 \mathrm{mg} / \mathrm{ml}$; Boehringer Mannheim, Mannheim, Germany) isolat- ed from segments of porcine thoracic aorta and cultured in M199 (Gibco-Invitrogen, Karlsruhe, Germany) supplemented with $10 \%$ (v/v) FCS (Gibco-Invitrogen), $100 \mathrm{mg} / \mathrm{l}$ penicillin $\mathrm{G}$, $100 \mathrm{mg} / \mathrm{l}$ streptomycin, $2 \mathrm{mmol} / \mathrm{l} \mathrm{L-glutamine}$ and $15 \mathrm{mmol} / \mathrm{l}$ HEPES, as described previously [25]. Experiments were performed with confluent cells in passage 2 seeded on glass coverslips.

Ratiometric imaging of fura-2 fluorescence. This method has been described previously $[25,26]$. Briefly, PAEC monolayers on coverslips were loaded in M199 with the cell-permeable fluorescent dye fura-2-acetomethoxyester (1 $\mu \mathrm{mol} / \mathrm{l})$ for $30 \mathrm{~min}$ at $37^{\circ} \mathrm{C}$; de-esterification of fura-2-acetomethoxyester to non-permeable fura- 2 was completed in fresh M199 by a further $15 \mathrm{~min}$ incubation at $37^{\circ} \mathrm{C}$. Fluorescence signals of intracellular fura-2- $\mathrm{Ca}^{2+}$ complexes were recorded at $25{ }^{\circ} \mathrm{C}$ on an inverted epifluorescence microscope (Diaphot TMD; Nikon, Tokyo, Japan) using a $\times 40$ objective lens (Fluor 40 ; Nikon). The excitation wavelength alternated every $0.5 \mathrm{~s}$ between 340 and $380 \mathrm{~nm}$; emission was monitored at $510 \mathrm{~nm}$. Intracellular $\mathrm{Ca}^{2+}$ was calculated from the $340 / 380 \mathrm{~nm}$ ratios of fluorescence intensities using the equation of Grynkiewicz et al. [26]. The traces represent the average intracellular $\mathrm{Ca}^{2+}$ concentration of 6 to 12 cells in the same microscopic field.

Measurement of superoxide generation

Superoxide generation was measured in immortalised HUVECs (EA.hy 926) [27] by lucigenin-enhanced chemiluminescence. The cells were grown to confluence on glass coverslips and then incubated for the times indicated with either high D-glucose or L-glucose (osmotic control) at $37{ }^{\circ} \mathrm{C}$. After addition of $2.5 \mu \mathrm{mol} / 1$ lucigenin, cumulative luminescence intensity was recorded for $60 \mathrm{~s}$ using the FB-12 Sirius SingleProbe Luminometer (Berthold detection systems, Pforzheim, Germany). The immortalised HUVECs (EA.hy 926) show morphologic and functional similarities to the primary PAECs; however, these primary cultures tend to de-differentiate, resulting in lower and less consistent signal intensities than the immortalised cultures. Hence, to obtain more reliable results, we used the EA.hy 926 cell line instead of the PAECs for monitoring the time course of glucose-induced superoxide formation.

Reverse transcription and PCR of $\mathrm{Na}^{+} /$glucose cotransporter- 1 mRNA

Total RNA was isolated from cloned porcine proximal tubule kidney cells (LLC-PK1), from PAECs in passage 2, and from the mechanically removed endothelial layer of freshly dissected PCA by guanidinium thiocyanate / phenol chloroform extraction [28]. The RNA was reversed-transcribed to cDNA using the Superscript First-Strand Synthesis System (Invitrogen, Karlsruhe, Germany). Aliquots of cDNA were amplified with primers specific for the $\mathrm{Na}+$ /glucose cotransporter- 1 (SGLT-1) and the housekeeping gene $\beta$-actin. To confirm identity, amplification products (SGLT-1 DNA bands) were sequenced in both directions by Taq dideoxy terminator cycle sequencing (ABI Prism BigDye Terminator v2.0 Cycle Sequencing Kit; Applied Biosystems, Foster City, Calif., USA).

\section{Data analysis}

Extrapolated $\mathrm{E}_{\max }$ and $\mathrm{EC}_{50}$ values of $\mathrm{NO}$ and tone measurements were derived from sigmoid regression curves of the con- 
a

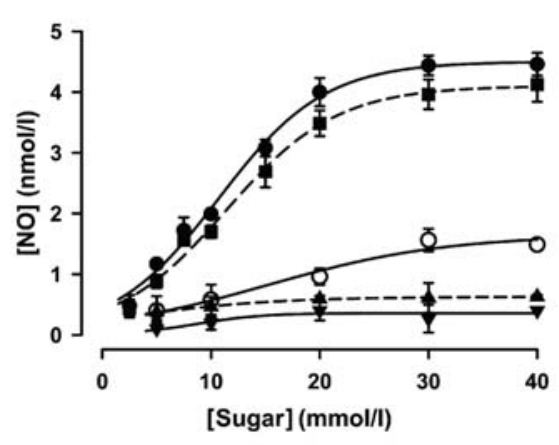

C

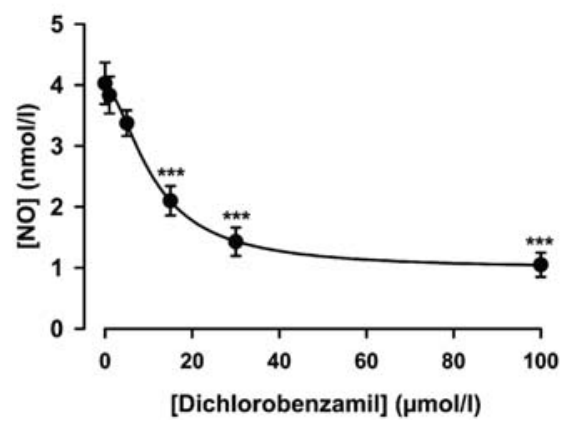

Fig. 1. Concentration-response curves of sugar-induced plateau NO release from PCAs after pre-incubation for 30-45 min in normal glucose buffer (5 mmol/l D-glucose). a. The NO release induced by D-galactose (black squares), L-glucose (black upward triangles), D-glucose (black circles), and D-glucose after NO synthase inhibition with $100 \mu \mathrm{mol} / \mathrm{l}$ L-NMMA (white circles) in PCAs, and D-glucose in endothelium-denuded arteries (black downward triangles). b. Original trace of the NO stimulation induced by $20 \mathrm{mmol} / \mathrm{l}$ D-glucose. c. The NO release induced by $20 \mathrm{mmol} / \mathrm{l} \mathrm{D}$-glucose after pre-incubation with increasing concentrations of the NCX blocker dichlorobenzamil. d. The NO release induced by $20 \mathrm{mmol} / \mathrm{l} \mathrm{D}-$ glucose after pre-incubation with increasing concentrations of the SGLT blocker phlorizin. The data points show the arithmetic means \pm SEM of 5 to 6 independent experiments each. $* p<0.05$; ** $p<0.01 ; * * * \quad p<0.001$ vs stimulation with $20 \mathrm{mmol} / \mathrm{l}$ D-glucose alone by two-tailed $t$ test

centration-response data and are expressed as arithmetic means $\pm 95 \%$ CI. Other values are expressed as means \pm SEM. Differences between means were assessed by the two-tailed $t$ test or ANOVA for multiple comparisons. A $p$ value of less than 0.05 was considered statistically significant.

\section{Results}

Acute effects of glucose on vascular nitric oxide formation. Acute stimulation of PCAs with D-glucose increased endothelial NO release in a concentration-dependent manner, producing an $\mathrm{E}_{\max }$ of $4.5 \pm 0.2 \mathrm{nmol} / \mathrm{l}$ $\mathrm{NO}$ at an $\mathrm{EC}_{50}$ of $10.7 \pm 1.0 \mathrm{mmol} / \mathrm{l} \mathrm{D}$-glucose $(n=6)$. The osmotic control (L-glucose) did not significantly b

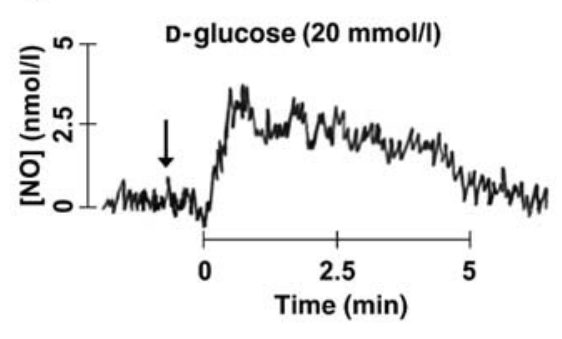

d

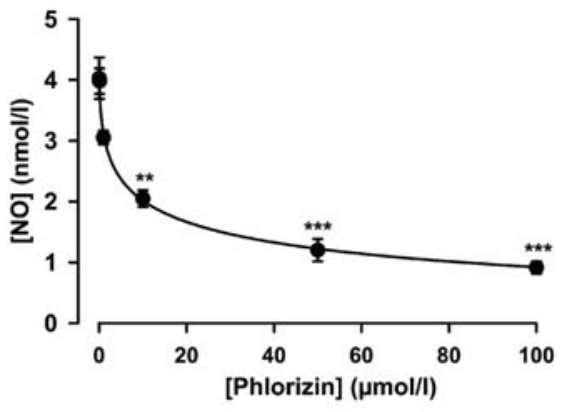

elevate NO levels (Fig. 1a). The maximum NO elevation achieved after stimulation with a single dose of $20 \mathrm{mmol} / \mathrm{l} \mathrm{D}$-glucose was $4.0 \pm 0.6 \mathrm{nmol} / \mathrm{l}$; the NO signal occurred after a delay of $0.9 \pm 0.2 \mathrm{~min}$ and showed a monophasic time course consisting of a plateau that lasted for $4.5 \pm 0.4 \mathrm{~min}(n=6)$ (Fig. 1b). In endothelium-denuded PCAs, D-glucose did not induce NO release, thus identifying the endothelial layer as the only source of NO. The NO-releasing effects of high D-glucose were blunted in the presence of the non-selective nitric oxide synthase inhibitor $\mathrm{L}-\mathrm{N}^{\mathrm{G}}$-monomethyl arginine (L-NMMA, $100 \mu \mathrm{mol} / \mathrm{l} ; \mathrm{E}_{\max }=1.6 \pm 0.3 \mathrm{nmol} / \mathrm{l}$, $n=6)$. Conversely, the response was not diminished in the presence of $1400 \mathrm{~W}$, a specific inhibitor of the inducible and neuronal isoforms of nitric oxide synthase (5 $\mu \mathrm{mol} / 1 ; \mathrm{E}_{\max }=4.4 \pm 0.4 \mathrm{nmol} / \mathrm{l}, n=6$ ). This finding suggests that the D-glucose-mediated increase in NO was entirely due to stimulation of the endothelial isoform of nitric oxide synthase (eNOS).

Involvement of $\mathrm{Ca} 2+$ in glucose-induced nitric oxide formation. It is well established that eNOS is activated by an increase in intracellular $\mathrm{Ca}^{2+}$. Since the NO response to high D-glucose was depressed in the presence of a low extracellular concentration of $\mathrm{Ca}^{2+}$ and in the presence of $\mathrm{Ni}^{2+}$ (an inhibitor of divalent cation entry) (Table 1), stimulation of eNOS by D-glucose is likely to involve an influx of extracellular $\mathrm{Ca}^{2+}$. We therefore investigated whether $\mathrm{Ca}^{2+}$-dependent eNOS stimulation is mediated by activation of endothelial receptor-operated $\mathrm{Ca}^{2+}$ channnels. However, neither inhibition of capacitative $\mathrm{Ca}^{2+}$ entry by SK\&F 96365 , nor inhibition of the cAMP-dependent opening of 
Table 1. Acute effect of high D-glucose and related sugars on nitric oxide release from PCAs

\begin{tabular}{|c|c|c|}
\hline Conditions & NO plateau concentration (nmol/l) & NO plateau duration (s) \\
\hline $\begin{array}{l}\text { D-Glucose }(20 \mathrm{mmol} / \mathrm{l}) \\
\text { D-Galactose }(20 \mathrm{mmol} / \mathrm{l}) \\
\text { D-Glucose }(20 \mathrm{mmol} / \mathrm{l}) \text { plus: }\end{array}$ & $\begin{array}{l}4.0 \pm 0.3 \\
3.5 \pm 0.2\end{array}$ & $\begin{array}{l}269 \pm 23 \\
245 \pm 25\end{array}$ \\
\hline $\begin{array}{l}\text { low extracellular } \mathrm{Ca}^{2+}\left(50 \mathrm{nmol} / 1 \mathrm{CaCl}_{2}\right) \\
\text { low extracellular } \mathrm{Na}^{+}(20 \mathrm{mmol} / \mathrm{l} \mathrm{NaCl}) \\
\mathrm{NiCl}_{2}(2 \mathrm{mmol} / \mathrm{l}) \\
\mathrm{SK} \& \mathrm{~F} 96365(20 \mu \mathrm{mol} / \mathrm{l}) \\
\text { ddAdoPP }(1 \mu \mathrm{mol} / \mathrm{l}) \\
\mathrm{LaCl}_{3}(1 \mathrm{mmol} / \mathrm{l}) \\
\text { thapsigargin }(1 \mu \mathrm{mol} / \mathrm{l}) \\
\text { dichlorobenzamil }(30 \mu \mathrm{mol} / \mathrm{l}) \\
\text { phlorizin }(100 \mu \mathrm{mol} / \mathrm{l}) \\
\text { cytochalasin } \mathrm{B}(1 \mu \mathrm{mol} / \mathrm{l})\end{array}$ & $\begin{array}{l}0.7 \pm 0.1^{\mathrm{b}} \\
0.6 \pm 0.3^{\mathrm{b}} \\
1.2 \pm 0.7^{\mathrm{a}} \\
3.6 \pm 0.3 \\
4.2 \pm 0.2 \\
4.0 \pm 0.3 \\
4.0 \pm 0.3 \\
1.4 \pm 0.2^{\mathrm{b}} \\
0.9 \pm 0.1^{\mathrm{a}} \\
5.7 \pm 0.2^{\mathrm{a}}\end{array}$ & $\begin{array}{c}28 \pm 14^{\mathrm{b}} \\
30 \pm 10^{\mathrm{b}} \\
36 \pm 22^{\mathrm{b}} \\
227 \pm 24 \\
256 \pm 18 \\
255 \pm 26 \\
267 \pm 20 \\
58 \pm 14^{\mathrm{b}} \\
42 \pm 11^{\mathrm{b}} \\
377 \pm 19^{\mathrm{a}}\end{array}$ \\
\hline
\end{tabular}

PCA segments were preincubated for 30-45 min in normal glucose buffer $(5 \mathrm{mmol} / \mathrm{l} \mathrm{D}$-glucose $)$ in the presence of the indicated test substances. Values shown are the means \pm SEM of
5 or 6 independent experiments. ${ }^{\mathrm{a}} p<001 \mathrm{~b}^{\mathrm{b}} p<0001$ vs stimulation with $20 \mathrm{mmol} / \mathrm{l}$ of sugar alone by two-tailed $t$ test plasmalemmal $\mathrm{Ca}^{2+}$ channels by the adenylate cyclase blocker 2',5'-dideoxyadenosine-3'-diphosphate (ddAdoPP), diminished the NO response to D-glucose (Table 1).

Acute effects of glucose on intracellular Ca2+. The crucial role of $\mathrm{Ca}^{2+}$ in the $\mathrm{NO}$ response to D-glucose was supported by direct measurement of total intracellular $\mathrm{Ca}^{2+}$ concentrations in PAECs using fura-2 fluorescence. Supplementation of normal glucose buffer ( $5 \mathrm{mmol} / \mathrm{l} \mathrm{D}$-glucose) with an additional $20 \mathrm{mmol} / \mathrm{l}$ D-glucose caused a small transient increase in intracellular $\mathrm{Ca}^{2+}$. The osmolar control $(20 \mathrm{mmol} / \mathrm{l} \mathrm{L}$-glucose $)$ did not change resting intracellular $\mathrm{Ca}^{2+}$ levels (Fig. 2a, Table 2). The D-glucose-mediated rise in intracellular $\mathrm{Ca}^{2+}$ was lost after the abolition of the transmembrane $\mathrm{Ca}^{2+}$ gradient and in the presence of $\mathrm{Ni}^{2+}$ (Table 2).

Involvement of Ca2+ transporters in glucose-mediated eNOS activation. Cytoplasmic calcium homeostasis is largely regulated by the plasma membrane $\mathrm{Ca}^{2+}$ ATPase (PMCA), the endoplasmic $\mathrm{Ca}^{2+}$ ATPase (SERCA), and the plasmalemmal $\mathrm{Na}^{+} / \mathrm{Ca}^{2+}$ exchanger (NCX) [29]. Inhibition of PMCA with $\mathrm{La}^{3+}$, or SERCA with thapsigargin (for $\geq 30$ min following the initial NO stimulation produced by delayed cytoplasmic $\mathrm{Ca}^{2+}$ removal) did not affect the D-glucose-induced endothelial NO response. This suggests that the $\mathrm{Ca}^{2+}$ dependent activation of eNOS by D-glucose does not involve the inhibition of cytoplasmic $\mathrm{Ca}^{2+}$ clearance by the outward rectifying $\mathrm{Ca}^{2+}$ pumps or the refilling of internal $\mathrm{Ca}^{2+}$ stores (Table 1). However, the NCX inhibitor dichlorobenzamil prevented the D-glucose- induced NO release in a concentration-dependent manner (Fig. 1c). The NCX is driven by the plasmalemmal $\mathrm{Na}^{+}$gradient. Thus, on removal of the transmembrane $\mathrm{Na}^{+}$gradient by the substitution of normal $\mathrm{Na}^{+}$buffer $\left(140 \mathrm{mmol} / \mathrm{l} \mathrm{Na}{ }^{+}\right)$with a low $\mathrm{Na}^{+}$solution (20 mmol/ $/ \mathrm{Na}^{+}$plus $120 \mathrm{mmol} / \mathrm{l}$ choline chloride as osmotic substitute), D-glucose-induced NO elevations were lost (Table 1). Similarly, when PCAs previously incubated in normal glucose and sodium buffer were treated with the $\mathrm{Na}^{+}$ionophore monensin $(10 \mu \mathrm{mol} / \mathrm{l})$, increasing the intracellular $\mathrm{Na}^{+}$concentration, the extent and duration of NO release was similar to that observed with high D-glucose $(5.3 \pm 0.2 \mathrm{nmol} / \mathrm{l} \mathrm{NO}$ and $5.2 \pm 0.4 \mathrm{~min}$ respectively, $n=6$ ). Co-incubation of monensin $(10 \mu \mathrm{mol} / \mathrm{l})$ with dichlorobenzamil (30 $\mu \mathrm{mol} / \mathrm{l})$ reduced the maximal NO signal to $1.8 \pm 0.2 \mathrm{nmol} / 1 \mathrm{NO}(p<0.001, n=5)$. Modulation of NO was accompanied by corresponding effects on intracellular $\mathrm{Ca}^{2+}$. In PAECs, the D-glucose-induced increase in intracellular $\mathrm{Ca}^{2+}$ was completely blocked by the presence of dichlorobenzamil (Fig. 2c), while stimulation with monensin elicited a transient plateaulike increase in intracellular $\mathrm{Ca}^{2+}$ (Fig. 2b).

Coupling of high glucose with NCX-dependent eNOS activation. The NO response to $20 \mathrm{mmol} / \mathrm{l} \mathrm{D}$-glucose (but not to L-glucose) was enhanced after blocking GLUT1 with cytochalasin B, the plateau NO increase and duration of the plateau being about $40 \%$ higher than the corresponding values in the absence of cytochalasin B (Table 1). The cytochalasin B-enhanced NO response was strongly related to a greater and longer-lasting intracellular $\mathrm{Ca}^{2+}$ response (Fig. 2a, Table 2). In contrast, specific competitive inhibition of 
a

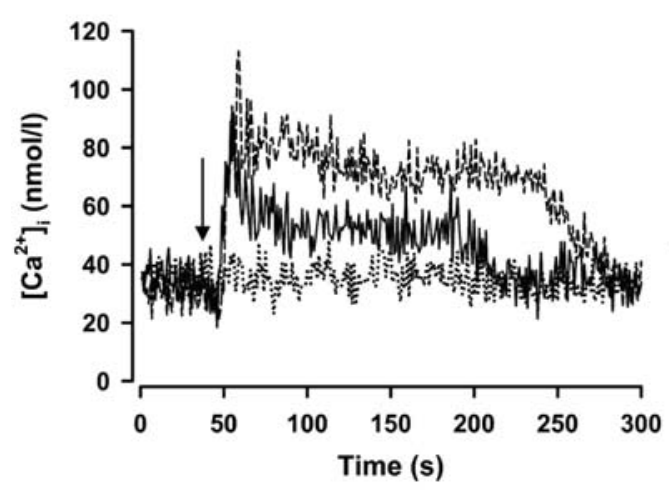

C

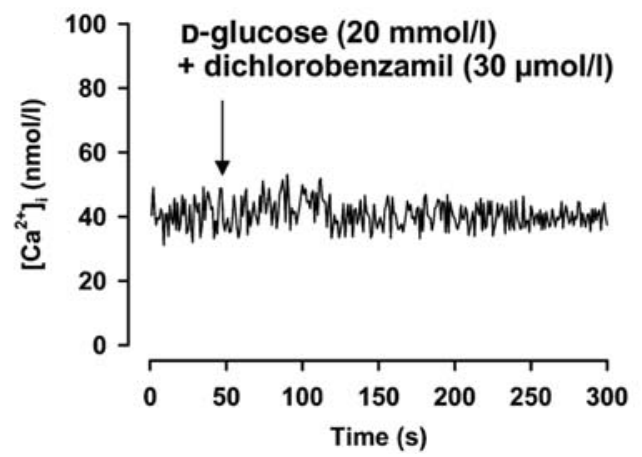

Fig. 2. Original traces of free intracellular calcium in PAECs. a. The increase in intracellular $\mathrm{Ca}^{2+}$ after stimulation with $20 \mathrm{mmol} / \mathrm{l} \mathrm{L}$-glucose (dotted line, bottom), D-glucose (solid line, middle), and D-glucose following pre-treatment for $30 \mathrm{~min}$ with $1 \mu \mathrm{mol} / \mathrm{l}$ cytochalasin B (dashed graph, top). b. The increase in intracellular $\mathrm{Ca}^{2+}$ induced by $10 \mu \mathrm{mol} / \mathrm{l}$ of b

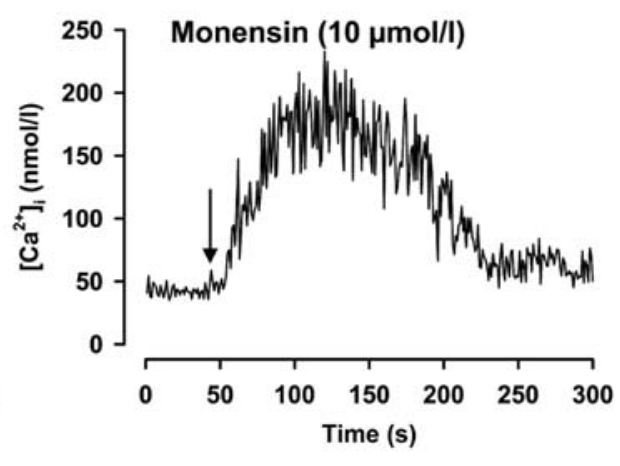

d

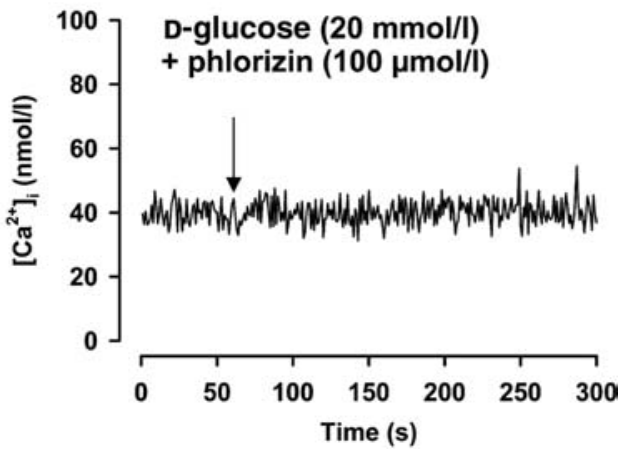

the sodium ionophore monensin. c. The increase in intracellular $\mathrm{Ca}^{2+}$ after stimulation of PAECs with $20 \mathrm{mmol} / \mathrm{l} \mathrm{D}$-glucose after pre-treatment with $30 \mu \mathrm{mol} / 1$ dichlorobenzamil. d. The increase in intracellular $\mathrm{Ca}^{2+}$ after stimulation of PAECs with $20 \mathrm{mmol} / \mathrm{l} \mathrm{D}$-glucose after pre-treatment with $100 \mu \mathrm{mol} / \mathrm{l}$ phlorizin

Table 2. Sugar-induced increases in intracellular $\mathrm{Ca}^{2+}$ in PAECs

\begin{tabular}{|c|c|c|}
\hline Conditions & $\Delta \mathrm{Ca}^{2+}{ }_{\mathrm{i}}(\mathrm{nmol} / \mathrm{l})$ & $\Delta \mathrm{Ca}^{2+}{ }_{\mathrm{i}}(\mathrm{s})$ \\
\hline D-glucose (20 mmol/l) (control) & $37.7 \pm 4.3$ & $187 \pm 19$ \\
\hline D-galactose $(20 \mathrm{mmol} / \mathrm{l})$ & $31.7 \pm 1.7$ & $158 \pm 10$ \\
\hline \multicolumn{3}{|l|}{ D-glucose $(20 \mathrm{mmol} / \mathrm{l})$ after $30 \mathrm{~min}$ pre-incubation under the following conditions: } \\
\hline low extracellular calcium $(50 \mathrm{nmol} / \mathrm{l})$ & $6.7 \pm 3.3^{\mathrm{b}}$ & $28 \pm 15^{b}$ \\
\hline $\mathrm{NiCl}_{2}(2 \mathrm{mmol} / \mathrm{l})$ & $8.3 \pm 3.3^{\mathrm{b}}$ & $32 \pm 4^{b}$ \\
\hline phlorizin $(100 \mu \mathrm{mol} / \mathrm{l})$ & $4.5 \pm 2.6^{\mathrm{c}}$ & $15 \pm 10^{c}$ \\
\hline cytochalasin B $(1 \mu \mathrm{mol} / \mathrm{l})$ & $61.7 \pm 4.4^{\mathrm{a}}$ & $243 \pm 9 b$ \\
\hline \multicolumn{3}{|l|}{ D-galactose $(20 \mathrm{mmol} / \mathrm{l})$ after $30 \mathrm{~min}$ pre-incubation under the following conditions: } \\
\hline cytochalasin B $(1 \mu \mathrm{mol} / \mathrm{l})$ & $58.6 \pm 3.2^{b}$ & $220 \pm 14^{b}$ \\
\hline phlorizin $(100 \mu \mathrm{mol} / \mathrm{l})$ & $3.0 \pm 0.9^{\mathrm{c}}$ & $16 \pm 11^{\mathrm{c}}$ \\
\hline Co-incubation of D-glucose $(20 \mathrm{mmol} / \mathrm{l})$ with insulin $(5 \mathrm{IU} / \mathrm{l})$ & $36.3 \pm 4.7$ & $178 \pm 11$ \\
\hline
\end{tabular}

Values shown are the arithmetic means \pm SEM of 3 to 4 independent experiments. $\Delta \mathrm{Ca}^{2+}{ }_{\mathrm{i}}(\mathrm{nmol} / \mathrm{l})$ is the difference between intracellular $\mathrm{Ca}^{2+}$ after stimulation and basal $\mathrm{Ca}^{2+}$; while
$\Delta \mathrm{Ca}^{2+}{ }_{\mathrm{i}}$ (s) is the duration of $\mathrm{Ca}^{2+}$ elevation. ${ }^{\mathrm{a}} p<005 ;{ }^{\mathrm{b}} p<001$; ${ }^{c} p<0001$ vs stimulation with $20 \mathrm{mmol} / \mathrm{l} \mathrm{D}$-glucose alone (control) by two-tailed $t$ test 


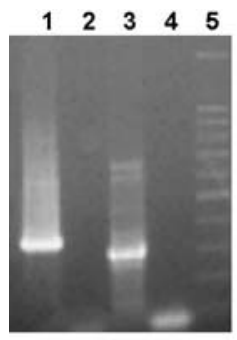

LLC-PK1

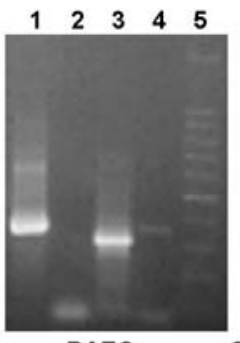

PAEC

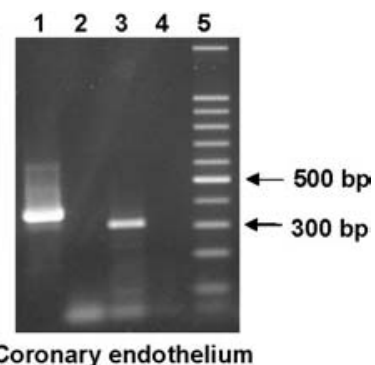

Fig. 3. PCR of cDNA derived from the total RNA of different porcine cell types. Lane $1, \beta$-actin (363 bp); Lane 2, $\beta$-actin (negative control, i.e. RT-PCR without the reverse transcriptase); Lane 3, SGLT-1 (308 bp); Lane 4, SGLT-1 (negative control); and Lane 5, DNA ladder (100-1500 bp). The following oligonucleotide primers were used: SGLT-1 (sense) 5'-CTG GAT CCA GAG GAG GAG GAC AT-3'; SGLT-1 (antisense) 5'-GCC TGC AGG GCA CAG CCT GTG-3' [49]; $\beta$-actin (sense) $5^{\prime}$-TCC CTG GAG AAG AGC TAC GA-3'; and $\beta$-actin (antisense) 5'-ACA TCT GCT GGA AGG TGG AC-3'

a
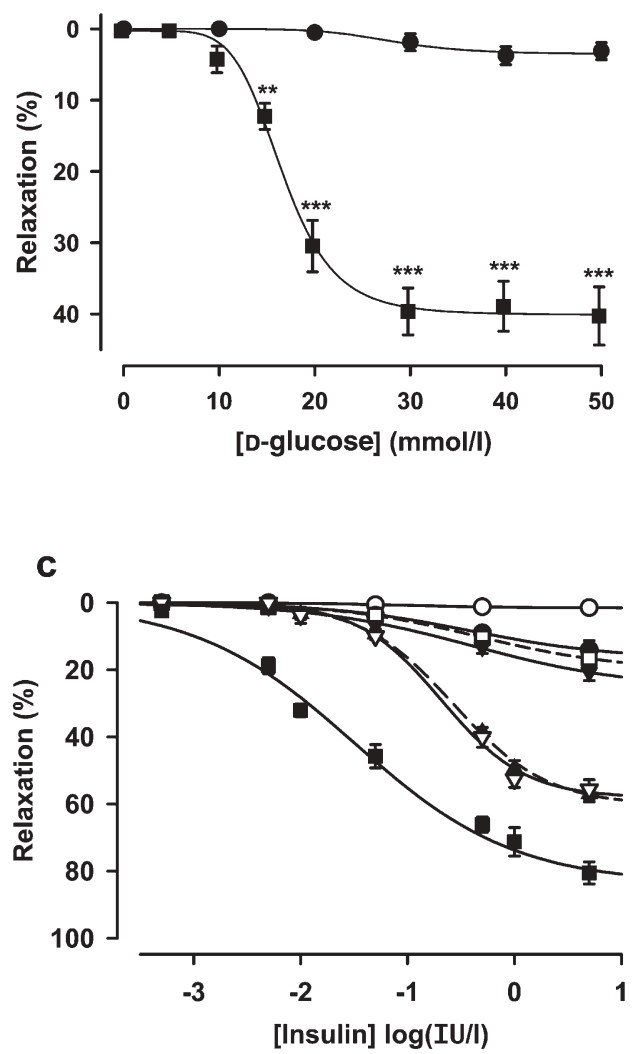

Fig. 4. Relaxation of PCAs. a. Concentration-response curves of relaxation induced by D-glucose after pre-incubation of PCAs in normal glucose buffer $(5 \mathrm{mmol} / \mathrm{l} \mathrm{D}$-glucose) for $30 \mathrm{~min}$ in the absence (black circles) and presence of $1 \mu \mathrm{mol} / \mathrm{l}$ cytochalasin B (black squares). b. Amplification of insulin-induced relaxation (5 IU/l insulin, dashed line) by co-incubation with increasing concentrations of D-glucose. c. Concentration-response curves of relaxation induced by: insulin alone (black upward triangles); co-stimulation with insulin plus $20 \mathrm{mmol} / \mathrm{l} \mathrm{D}$-glucose (black squares) or L-glucose (white downward triangles); insulin after 30 min pre-incubation with $100 \mu \mathrm{mol} / 1$ L-NMMA (black circles), $25 \mu \mathrm{mol} / \mathrm{l}$ genistein
SGLTs with phlorizin suppressed the D-glucose-induced NO response in a concentration-dependent manner (Fig. 1d), and abolished the increase in intracellular calcium (Fig. 2d). The transporter isoforms SGLT-1 and GLUT1 have been shown to transport D-galactose as efficiently as D-glucose [30, 31]. Accordingly, the effect of D-galactose on endothelial NO release $\left(\mathrm{E}_{\max }=4.1 \pm 0.4 \mathrm{nmol} / \mathrm{l}, 4.2 \pm 0.3 \mathrm{~min}, n=5\right)$ (Fig. 1a, Table 1) and intracellular $\mathrm{Ca}^{2+}$ (Table 2) was similar to that observed with D-glucose. Both of these responses were blocked in the presence of phlorizin, and were enhanced by cytochalasin B (Tables 1 and 2).

PCR analysis. Amplification and sequencing of cDNA obtained from porcine coronary and aortic endothelial cells with SGLT-1-specific primers confirmed the presence of SGLT-1 mRNA in vascular endothelium,

b

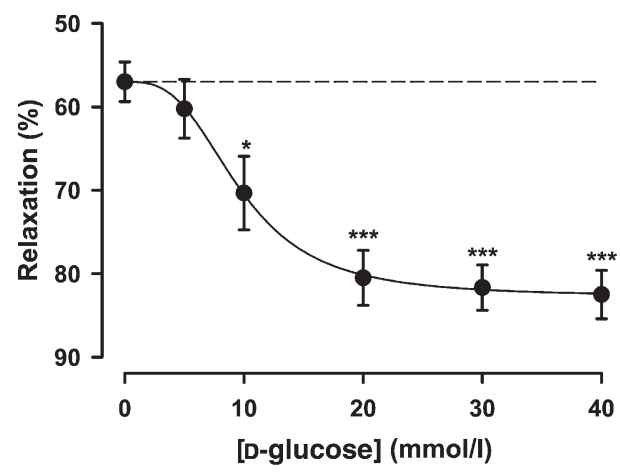

d

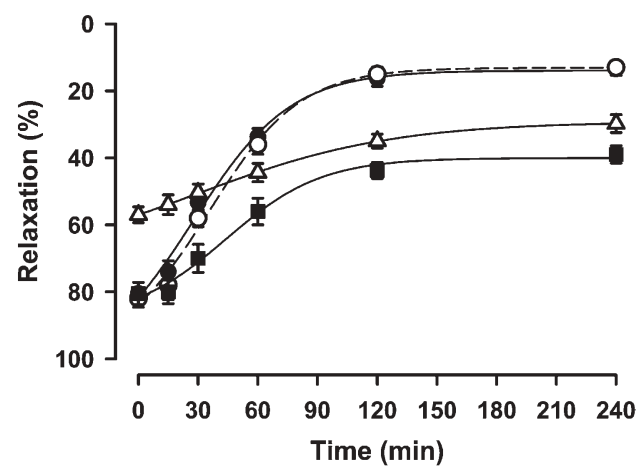

(white squares) or $1 \mu \mathrm{mol} / \mathrm{l}$ wortmannin (black downward triangles); and by insulin in endothelium-denuded arteries (white circles). d. Effect of pre-incubation time in high glucose buffer ( $25 \mathrm{mmol} / \mathrm{l} \mathrm{D}$-glucose) on relaxation in response to $5 \mathrm{IU} / \mathrm{l}$ insulin alone (black circles) or to $5 \mathrm{IU} / \mathrm{l}$ insulin plus $20 \mathrm{mmol} / \mathrm{l} \mathrm{D}-$ glucose (white circles) compared with the effect of pre-incubation in high glucose buffer followed by $60 \mathrm{~min}$ incubation in normal glucose buffer on relaxation in response to $5 \mathrm{IU} / \mathrm{l}$ insulin (white upward triangles) or to $5 \mathrm{IU} / \mathrm{l}$ insulin plus $20 \mathrm{mmol} / \mathrm{l}$ D-glucose (black squares). Data points show the arithmetic means \pm SEM of 4-6 independent experiments. * $p<0.05$; $* * p<0.01$; *** $p<0.001$ vs control by two-tailed $t$ test 
a

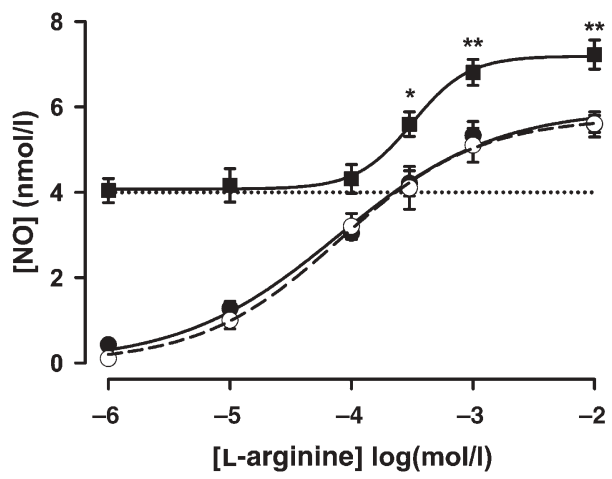

Fig. 5. Glucose-mediated amplification of L-arginine-induced NO release (a) and relaxation (b) PCAs. PCA segments were incubated in normal D-glucose buffer $(5 \mathrm{mmol} / \mathrm{l})$ for $1 \mathrm{~h}$ prior to stimulation with L-arginine (black circles), L-arginine plus $20 \mathrm{mmol} / \mathrm{l}$ D-glucose (black squares), or L-arginine + $20 \mathrm{mmol} / \mathrm{l} \mathrm{L}$-glucose (white circles). Data points show the arithmetic means \pm SEM of 4 or 5 independent experiments. $* p<0.05 ; * * p<0.01$ vs L-arginine alone by two-tailed $t$ test

with cDNA from LLC-PK1 cells serving as a positive control [32] (Fig. 3).

Acute effects of glucose on vascular tone. Although D-glucose induced NO release, in myographic experiments, stimulation of PCA rings incubated in normal glucose buffer (5 mmol/l glucose) with additional D-glucose (up to $50 \mathrm{mmol} / \mathrm{l}$ ) did not alter vascular tone (Fig. 4a). The hyperosmotic control, L-glucose, and D-galactose also failed to cause significant relaxation or contraction. Similarly, stimulation of endothelium-denuded PCA rings with high D-glucose did not affect vascular tone (data not shown). However, following pre-incubation of vessels with cytochalasin $\mathrm{B}$, the addition of $20 \mathrm{mmol} / \mathrm{l} \mathrm{D}$-glucose or D-galactose to endothelium-intact PCAs induced marked relaxation (Fig. 4a).

Involvement of glucose-facilitated arginine transport in nitric oxide formation and relaxation. Additionally, we investigated whether D-glucose amplified the stimulatory effect of the eNOS substrate L-arginine on NO release and vasodilation. The addition of $20 \mathrm{mmol} / \mathrm{l}$ D-glucose moderately (in a sub-additive manner) enhanced NO formation and relaxation in response to $\mathrm{L}$-arginine. However, this effect attained significance only at L-arginine concentrations of $\geq 0.3 \mathrm{mmol} / \mathrm{l}$ and was absent when L-arginine was co-incubated with 20 mmol/l L-glucose (Fig. 5).

Additive effects of d-glucose and insulin on nitric oxide formation and vasorelaxation. Stimulation of PCAs with insulin in normal glucose buffer $(5 \mathrm{mmol} / \mathrm{l} \mathrm{glu}$ cose) increased endothelial NO formation in a concentration-dependent manner, producing an $\mathrm{E}_{\max }$ of $7.9 \pm 0.8 \mathrm{nmol} / \mathrm{l} \mathrm{NO}$ at an $\mathrm{EC}_{50}$ of $24.3 \pm 4.5 \mathrm{mU} / \mathrm{l}$ insu- b

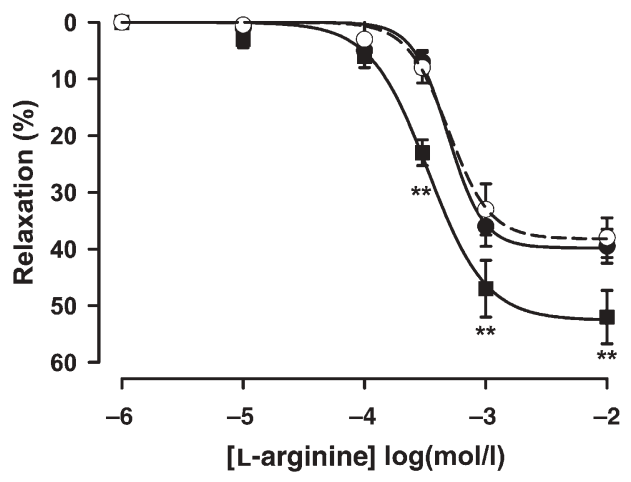

lin (Fig. 6a). This effect was abolished in the presence of the receptor/tyrosine kinase (RTK) blocker genistein and the phosphatidylinositol 3'-OH kinase (PI3 K) blocker wortmannin (Fig. 6b), but remained unchanged in the presence of $\mathrm{Ni}^{2+}$, phlorizin and dichlorobenzamil (Table 3). Compared with insulin alone, simultaneous stimulation of PCAs with insulin and increasing concentrations of D-glucose (but not L-glucose) amplified the endothelial NO response in a concentration-dependent and additive fashion (Fig. 6a,c). Co-stimulation with D-galactose and insulin evoked a similar potentiation of the NO signal (Fig. 6b, Table 3). Pre-treatment of PCAs with genistein or wortmannin reduced the NO response to combinations of insulin and high glucose to levels observed on insulin stimulation alone (Fig. 6b), whereas pre-treatment with phlorizin reduced the response to levels seen on high glucose stimulation alone (Table 3). Together, wortmannin and phlorizin almost completely suppressed the high D-glucose/insulin-induced NO elevation, producing results similar to those obtained when endothelium-denuded PCAs were employed (Fig. 6a). The combination of high D-glucose/insulin plus cytochalasin B provoked a further amplification of the NO signal, while cytochalasin B did not amplify the NO response to insulin in normal glucose buffer (Table 3).

Treatment of PCA rings with insulin plus high D-glucose (but not L-glucose) amplified insulin-dependent relaxation in a concentration-dependent manner (Fig. 4b). Relaxation was further increased by preincubation with cytochalasin B (Table 4), and was blunted by L-NMMA, genistein and wortmannin. Endothelium-denuded vessels completely failed to relax in response to insulin plus high D-glucose (Fig. 4c). There were no differences in the extent of inhibition in the presence or absence of high D-glucose (Table 4). Pre-treatment of PCAs with $\mathrm{Ni}^{2+}$, dichlorobenzamil or phlorizin reduced relaxation to levels observed with insulin stimulation alone (Table 4). Co-incubation with insulin and D-galactose mimicked the potentiating effects of D-glucose (Table 4).

Nitric oxide response and vasorelaxation after prolonged glucose overload. Prolonged exposure of coronary rings to high $\mathrm{D}$-glucose caused a progressive loss 
a

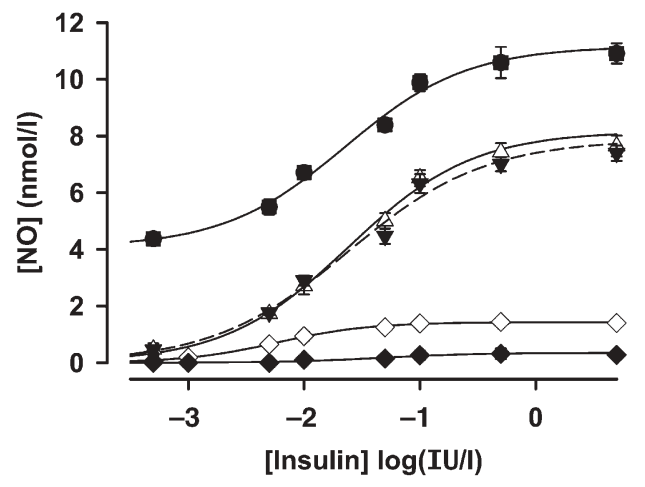

C

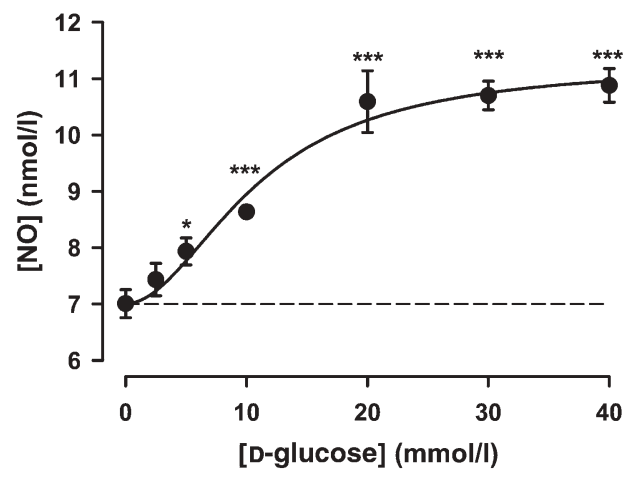

d

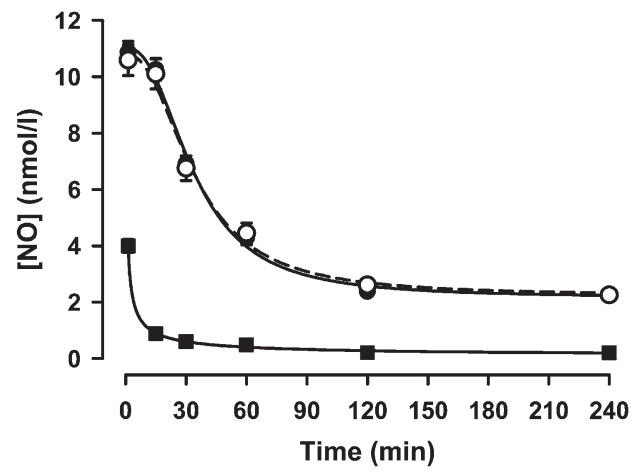

Fig. 6. Effects of glucose on insulin-induced NO release from PCAs. a. Concentration-response curves of NO release stimulated by: different concentrations of insulin alone (black downward triangles); by insulin plus $20 \mathrm{mmol} / \mathrm{l} \mathrm{D-glucose} \mathrm{(black}$ squares) or L-glucose (white upward triangles); insulin plus $20 \mathrm{mmol} / \mathrm{l} \mathrm{D}$-glucose after $30 \mathrm{~min}$ pre-incubation with $1 \mu \mathrm{mol} / \mathrm{l}$ wortmannin and $100 \mu \mathrm{mol} / \mathrm{l}$ phlorizin (white diamonds); and insulin plus $20 \mathrm{mmol} / \mathrm{l} \mathrm{D}$-glucose in endothelium-denuded arteries (black diamonds). b. The NO release induced by: co-stimulation of insulin with $20 \mathrm{mmol} / \mathrm{l} \mathrm{D}$-galactose (black squares); insulin alone after $30 \mathrm{~min}$ pre-incubation of PCAs with $25 \mu \mathrm{mol} / \mathrm{l}$ genistein (white circles) or $1 \mu \mathrm{mol} / \mathrm{l}$ wortmannin (black circles); and insulin plus $20 \mathrm{mmol} / \mathrm{l} \mathrm{D}$-glucose after 30 min pre-incubation of PCAs with $25 \mu \mathrm{mol} / 1$ genistein (white downward triangles) or $1 \mu \mathrm{mol} / \mathrm{l}$ wortmannin (black upward triangles). The dashed line indicates the mean NO stimulation b

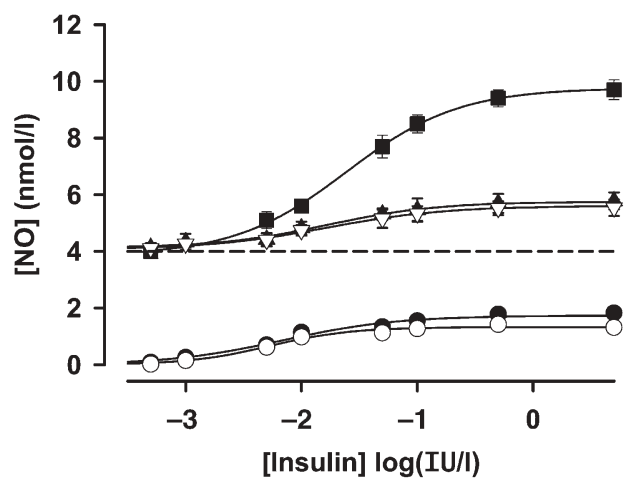

e

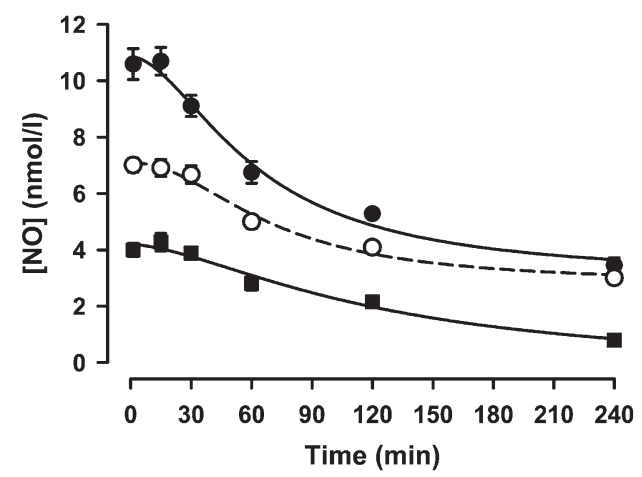

by $20 \mathrm{mmol} / \mathrm{l} \mathrm{D}$-glucose. c. Amplification of insulin-induced NO release ( 0.5 IU/l insulin, dashed line) by co-incubation with increasing concentrations of D-glucose. d. Effect of preincubation time in high glucose buffer $(25 \mathrm{mmol} / \mathrm{l} \mathrm{D}$-glucose) on NO release induced by $0.5 \mathrm{IU} / 1$ insulin alone (white circles), $20 \mathrm{mmol} / \mathrm{l} \mathrm{D-glucose}$ alone (black squares), and by costimulation with $0.5 \mathrm{IU} / 1$ insulin plus $20 \mathrm{mmol} / 1 \mathrm{D}$-glucose (black circles). e. Effect of pre-incubation of PCAs in high glucose buffer followed by $60 \mathrm{~min}$ incubation in normal glucose buffer $(5 \mathrm{mmol} / \mathrm{l}$ D-glucose) on NO release induced by $0.5 \mathrm{IU} / \mathrm{l}$ insulin alone (white circles), $20 \mathrm{mmol} / \mathrm{l} \mathrm{D}$-glucose alone (black squares), and by co-stimulation with $0.5 \mathrm{IU} / 1$ insulin plus $20 \mathrm{mmol} / \mathrm{l} \mathrm{D}$-glucose (black circles). Data points show the arithmetic means \pm SEM of 5 or 6 independent experiments. $* p<0.05$; ** $p<0.01$; *** $p<0$.vs stimulation with $0.5 \mathrm{IU} / \mathrm{l}$ insulin alone by two-tailed $t$ test 
Table 3. Effects of glucose on insulin-induced NO release from PCAs

\begin{tabular}{|c|c|c|c|c|c|c|}
\hline & \multicolumn{6}{|c|}{ NO (nmol/1) } \\
\hline & $\begin{array}{l}5 \mathrm{mIU} / 1 \\
\text { insulin }\end{array}$ & $\begin{array}{l}5 \mathrm{mIU} / \mathrm{linsulin}+ \\
20 \mathrm{mmol} / \mathrm{l} \\
\text { D-glucose }\end{array}$ & $\begin{array}{l}50 \mathrm{mIU} / 1 \\
\text { insulin }\end{array}$ & $\begin{array}{l}50 \mathrm{mIU} / \mathrm{l} \text { insulin }+ \\
20 \mathrm{mmol} / \mathrm{l} \\
\text { D-glucose }\end{array}$ & $\begin{array}{l}500 \mathrm{mIU} / 1 \\
\text { insulin }\end{array}$ & $\begin{array}{l}500 \mathrm{mIU} / \mathrm{l} \text { insulin }+ \\
20 \mathrm{mmol} / \mathrm{l} \\
\text { D-glucose }\end{array}$ \\
\hline Control & $1.8 \pm 0.1$ & $5.5 \pm 0.3^{b}$ & $4.5 \pm 0.3$ & $8.4 \pm 0.2^{b}$ & $7.0 \pm 0.2$ & $10.6 \pm 0.5^{b}$ \\
\hline L-Glucose $(20 \mathrm{mmol} / \mathrm{l})$ & $1.8 \pm 0.2$ & $5.4 \pm 0.4^{b}$ & $5.0 \pm 0.3$ & $8.7 \pm 0.4^{b}$ & $7.4 \pm 0.3$ & $10.8 \pm 0.6^{b}$ \\
\hline Phlorizin $(100 \mu \mathrm{mol} / \mathrm{l})$ & $1.7 \pm 0.2$ & $1.8 \pm 0.2$ & $4.5 \pm 0.4$ & $4.6 \pm 0.2$ & $7.1 \pm 0.3$ & $7.5 \pm 0.5$ \\
\hline $\mathrm{NiCl}_{2}(2 \mathrm{mmol} / \mathrm{l})$ & $1.9 \pm 0.1$ & $2.2 \pm 0.2$ & $4.6 \pm 0.3$ & $4.5 \pm 0.4$ & $7.0 \pm 0.3$ & $6.8 \pm 0.3$ \\
\hline Cytochalasin B $(1 \mu \mathrm{mol} / \mathrm{l})$ & $1.7 \pm 0.1$ & $6.9 \pm 0.4^{b}$ & $4.5 \pm 0.2$ & $9.0 \pm 0.4^{b}$ & $7.3 \pm 0.5$ & $12.1 \pm 0.6^{\mathrm{a}}$ \\
\hline
\end{tabular}

PCA segments were pre-incubated for $60 \mathrm{~min}$ in normal glucose buffer (containing $5 \mathrm{mmol} / \mathrm{l} \mathrm{D}$-glucose) and then stimulated with insulin or insulin $+20 \mathrm{mmol} / \mathrm{l} \mathrm{D}$-glucose in the absence (control) or presence of the indicated substances. The L-glucose and D-galactose were applied together with the insulin so-

Table 4. Effects of D-glucose on insulin-induced relaxation of PCAs

\begin{tabular}{|c|c|c|}
\hline & \multicolumn{2}{|c|}{ Relaxation (\%) } \\
\hline & $5 \mathrm{IU} / \mathrm{l}$ insulin & $\begin{array}{l}5 \mathrm{IU} / \mathrm{l} \text { insulin } \\
+\mathrm{D}-\mathrm{glucose} \\
(20 \mathrm{mmol} / \mathrm{l})\end{array}$ \\
\hline Control & $57.0 \pm 2.4$ & $80.5 \pm 3.3^{b}$ \\
\hline L-Glucose $(20 \mathrm{mmol} / \mathrm{l})$ & $55.7 \pm 2.9$ & $78.7 \pm 3.0^{\mathrm{b}}$ \\
\hline D-Galactose $(20 \mathrm{mmol} / \mathrm{l})$ & $70.4 \pm 2.9^{a}$ & $82.4 \pm 4.1^{b}$ \\
\hline L-NMMA $(100 \mu \mathrm{mol} / \mathrm{l})$ & $11.8 \pm 1.9^{\mathrm{b}}$ & $14.1 \pm 2.8^{b}$ \\
\hline Genistein $(25 \mu \mathrm{mol} / \mathrm{l})$ & $13.6 \pm 2.5^{b}$ & $16.7 \pm 1.7^{b}$ \\
\hline Wortmannin $(1 \mu \mathrm{mol} / \mathrm{l})$ & $21.2 \pm 3.3^{b}$ & $20.8 \pm 2.4^{b}$ \\
\hline Dichlorobenzamil $(30 \mu \mathrm{mol} / \mathrm{l})$ & $57.8 \pm 2.6$ & $60.4 \pm 3.2$ \\
\hline Phlorizin $(100 \mu \mathrm{mol} / \mathrm{l})$ & $58.9 \pm 4.0$ & $58.3 \pm 2.6$ \\
\hline $\mathrm{NiCl}_{2}(2 \mathrm{mmol} / \mathrm{l})$ & $55.3 \pm 2.8$ & $56.0 \pm 2.9$ \\
\hline Cytochalasin B $(1 \mu \mathrm{mol} / \mathrm{l})$ & $566 \pm 21$ & $927 \pm 34^{b}$ \\
\hline
\end{tabular}

PCA rings were pre-incubated for $60 \mathrm{~min}$ in normal glucose buffer (containing $5 \mathrm{mmol} / \mathrm{l} \mathrm{D}$-glucose) and then stimulated with $5 \mathrm{IU} / \mathrm{l}$ insulin or $5 \mathrm{IU} / \mathrm{l}$ insulin plus $20 \mathrm{mmol} / \mathrm{l} \mathrm{D}$-glucose in the absence (control) or presence of the indicated substances. The L-glucose and D-galactose were applied at the same time as the insulin solutions while the other substances were added $30 \mathrm{~min}$ before the insulin solutions. Values shown are the arithmetic means \pm SEM of 4-6 independent experiments. ${ }^{\mathrm{a}} p<001 ;{ }^{\mathrm{b}} p<0001$ relaxation with $5 \mathrm{IU} / \mathrm{l}$ insulin alone by two-tailed $t$ test

of the acute stimulatory effects of both D-glucose and insulin on NO synthesis. After only $2 \mathrm{~h}$ of incubation with $25 \mathrm{mmol} / \mathrm{l} \mathrm{D}$-glucose, the potentiation of insulinmediated NO release by high D-glucose was absent (Fig. 6d). The observed effects on NO release were in accordance with myographic experiments. Prolonged treatment with $25 \mathrm{mmol} / \mathrm{l} \mathrm{D}$-glucose attenuated relaxation in response to insulin and abolished the potentiating effect of high D-glucose on insulin-mediated relaxation (Fig. 4d). The NO and vascular responses lutions while the other substances were added 30 min before the insulin solutions. Values shown are the arithmetic means \pm SEM of 5 or 6 independent experiments. ${ }^{\mathrm{a}} p<001 ;{ }^{\mathrm{b}} p<0001$ vs stimulation without D-glucose by two-tailed $t$ test

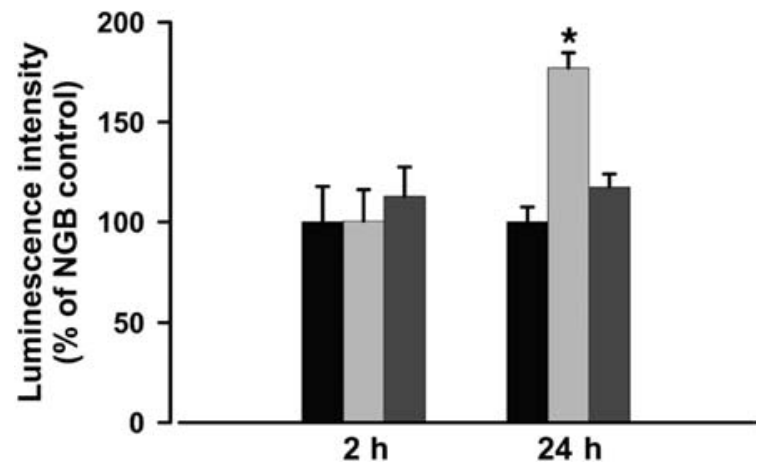

Fig. 7. Superoxide generation in EA.hy 926 cells after $2 \mathrm{~h}$ and $24 \mathrm{~h}$ of incubation in normal glucose buffer $(5 \mathrm{mmol} / \mathrm{l} \mathrm{D}$-glucose, black bars), $20 \mathrm{mmol} / \mathrm{l} \mathrm{D}$-glucose (light grey bars), and in $20 \mathrm{mmol} / \mathrm{l} \mathrm{L}$-glucose (dark grey bars). Chemiluminescence intensities are given relative to the normal glucose buffer (NGB) control. Values shown represent the arithmetic means \pm SEM of at least 8 experiments. * $p<0.001$ vs the normal glucose buffer control by two-tailed $t$ test with Holm correction

of the PCAs to combinations of insulin plus D-glucose were only partially restored by incubation for $1 \mathrm{~h}$ in normal glucose buffer (Figs. 4d, 6e).

An increase in endothelial cell superoxide formation was observed after $24 \mathrm{~h}$ of incubation with high D-glucose, but not after $2 \mathrm{~h}$ of incubation (Fig. 7); thus, we were able to rule out the possibility that NO bioavailability and consequent vasodilation were reduced by glucose-enhanced superoxide generation. In keeping with this finding, in PCAs incubated in $25 \mathrm{mmol} \mathrm{D}$-glucose for $2 \mathrm{~h}$, the NO and vascular responses to D-glucose or insulin could not be restored by co-incubation with the superoxide scavangers vitamin $\mathrm{C}(2 \mathrm{mmol} / \mathrm{l})$, trolox $(2 \mathrm{mmol} / \mathrm{l})$, superoxide dismutase (copper/zinc superoxide dismutase from bovine erythrocytes, $10 \mu \mathrm{mol} / \mathrm{l}$ ) or the cell-permeable SOD analogue $\mathrm{Mn}$ (III) tetra(4-benzoic acid)porphyrin chloride $(10 \mu \mathrm{mol} / \mathrm{l})$ (data not shown). 
Intracellular Ca2+ response after prolonged glucose overload. Stimulation of PAECs in normal glucose buffer with insulin (5 IU/l) did not alter intracellular $\mathrm{Ca}^{2+}$ concentrations (data not shown), while the response to insulin/high D-glucose was similar to that observed with to D-glucose alone (Table 2). Following incubation of the PAECs with $25 \mathrm{mmol} / \mathrm{l} \mathrm{D}$-glucose for $2 \mathrm{~h}$, stimulation with additional D-glucose did not elicit an increase in intracellular $\mathrm{Ca}^{2+}$. However, treatment of the glucose-loaded PAECs with normal glucose buffer for $1 \mathrm{~h}$ restored the stimulatory effect of D-glucose on intracellular $\mathrm{Ca}^{2+}$, although this effect was smaller than that induced by the initial glucose treatment of the cells (Table 2).

\section{Discussion}

Our findings indicate that elevated D-glucose concentrations in PCAs directly stimulate the release of NO from the endothelial layer. This effect was due to the activity of eNOS and was associated with an increase in intracellular $\mathrm{Ca}^{2+}$. The response was specific to the monomeric D-stereoisomer of glucose and was not mediated by an increase in osmotic pressure, since equimolar concentrations of L-glucose failed to elevate either $\mathrm{NO}$ or intracellular $\mathrm{Ca}^{2+}$. Inhibition of $\mathrm{NO}$ release by $\mathrm{Ni}^{2+}$ or by the absence of extracellular $\mathrm{Ca}^{2+}$ demonstrates that $\mathrm{Ca}^{2+}$ entry from the extracellular space is the essential trigger for the activation of eNOS.

Since the coronary endothelium lacks voltage-gated $\mathrm{Ca}^{2+}$ channels [33], two possible pathways exist for calcium influx: receptor-activated $\mathrm{Ca}^{2+}$ channels and plasmalemmal transport proteins.

Involvement of $\mathrm{Ca}^{2+}$ channels can be excluded, as neither inhibition of capacitative calcium entry nor inhibition of $\mathrm{Ca}^{2+}$ influx via cAMP-dependent cation channels altered the stimulatory effects of D-glucose on NO formation. Hence, we propose that the influx of extracellular $\mathrm{Ca}^{2+}$ is the result of a transport process that is either directly or indirectly activated by D-glucose.

Two transporters are reportedly involved in the regulation of $\mathrm{Ca}^{2+}$-dependent eNOS activity, namely, PMCA and NCX. These proteins are localised in the plasmalemmal caveolae in close proximity to eNOS and participate in the control of sub-plasmalemmal intracellular $\mathrm{Ca}^{2+}$, which is of particular importance for modulation of eNOS activity [34, 35]. The high affinity/low capacity PMCA is the principal $\mathrm{Ca}^{2+}$ removal system in vascular endothelium [36]. However, failure of the PMCA- (and capacitative $\mathrm{Ca}^{2+}$ entry-) inhibitor $\mathrm{La}^{3+}$ to diminish D-glucose-mediated NO formation suggests that intracellular $\mathrm{Ca}^{2+}$ clearance by PMCA is not involved in glucose-dependent eNOS activation. In contrast, the complete abolition of D-glucose-induced increases in endothelial intracellular $\mathrm{Ca}^{2+}$ and
NO release by inhibition of NCX indicates that stimulation of this protein is involved in the response to D-glucose. Previous reports have shown that $\mathrm{Ca}^{2+} \mathrm{ex}^{-}$ trusion by the low affinity/high capacity NCX system is triggered by intracellular $\mathrm{Na}^{+}$loading [34]. Glucose cannot cross intact membranes by diffusion; its intracellular uptake is achieved by glucose transport systems. Passive entry via the ubiquitous transcellular D-glucose gradient-driven facilitative glucose transporters (GLUT1) is well characterised. Recently, an alternative secondary active uptake pathway via SGLT has been identified in the endothelium of several vascular beds $[37,38]$. We hypothesised that elevation of the extracellular concentration of D-glucose would increase entry not only via GLUT1, but also via SGLT, leading to a rise in intracellular $\mathrm{Na}^{+}$which in turn stimulates $\mathrm{Ca}^{2+}$ uptake through NCX. This hypothesis is supported by the finding that the D-glucose-induced increase in intracellular $\mathrm{Ca}^{2+}$ and subsequent $\mathrm{NO}$ formation were completely blocked by the selective SGLT inhibitor phlorizin. The existence of functional SGLT in coronary artery endothelium is supported by the identification of SGLT-1 mRNA in aortic and coronary endothelium by RT-PCR in this study. It has been reported that GLUT1 and SGLT each contribute to approximately $50 \%$ of the glucose uptake in several vascular beds. Moreover, SGLT is rapidly desensitised by an increase in intracellular glucose concentrations [38]. Thus, selective inhibition of GLUT1 should delay desensitisation and therefore potentiate $\mathrm{Na}^{+}$uptake via SGLT, triggering an increased $\mathrm{Ca}^{2+}$ and NO response. This explains the elevated magnitude and duration of the D-glucose-induced increase in endothelial intracellular $\mathrm{Ca}^{2+}$ and $\mathrm{NO}$ release in the presence of cytochalasin B.

As we made comparable observations using D-galactose instead of D-glucose we were able to exclude other members of this SGLT family (SGLT-2 and SGLT-3), since SGLT-1 does not discriminate between D-glucose and D-galactose, while neither SGLT-2 nor SGLT-3 transport D-galactose efficiently $\left(\mathrm{K}_{\mathrm{m}}\right.$ $>20 \mathrm{mmol} / \mathrm{l}$ ) [31].

Although we have suggested a mechanism for glucose-induced endothelial NO release, the question remains whether this finding may be of physiological significance. A direct consequence of endothelial NO release is the relaxation of adjacent smooth muscle via activation of soluble guanylate cyclase. However, stimulation with high glucose alone had no effect on resting vascular tone. The apparent inability of high glucose to dilate coronary vessels may be explained by the relatively low magnitude of NO release. We recently reported that an increase in endothelial NO release of $>5 \mathrm{nmol} / \mathrm{l}$ was required to trigger vasodilation [24]. Consistent with this finding, an elevated glucose-induced increase in NO of $5.7 \mathrm{nmol} / \mathrm{l}$, achieved after inhibition of GLUT1, was sufficient to evoke relaxation. Moreover, we have demonstrated 
that the effect of the eNOS substrate L-arginine on NO release and vasodilation is enhanced by D-glucose in a concentration-dependent manner. This finding is in accordance with a report of Sobrevia et al. [39] which reported that D-glucose potentiates the uptake of $\mathrm{L}$-arginine in vascular endothelial cells via the sodium-independent $\mathrm{y}^{+}$-transport system. However, this mechanism of eNOS activation may only be relevant at high levels of of L-arginine, and is unlikely to occur at physiological plasma concentrations with baseline levels of about $90 \mu \mathrm{mol} / \mathrm{l}$ and post-prandial peaks of about $130 \mu \mathrm{mol} / 1[40,41]$.

In accordance with previous studies [42], the vasodilatory actions of insulin were confirmed to be endothelium-dependent, with eNOS activation mediated by receptor/tyrosine kinase, insulin receptor substrate (IRS-1), PI3K and serine/threonine protein kinase (Akt/PKB), but not $\mathrm{Ca}^{2+}$.

A key finding of our study is that the NO responses to insulin, as well as the relaxation responses, are potentiated by co-incubation with high D-glucose in a concentration-dependent fashion. The mechanism responsible for glucose-mediated amplification of the vascular response to insulin appears to be confined to SGLT- and NCX-activated, $\mathrm{Ca}^{2+}$-dependent eNOS stimulation, since inhibition of $\mathrm{Ca}^{2+}$ entry by inhibitors specific to $\mathrm{Ni}^{2+}$, SGLT or NCX completely abolished the additive glucose effect. We therefore conclude that an elevated plasma glucose level accelerates its own cellular uptake by NO-derived vasodilation, which is dependent on insulin- and glucose-stimulated endothelial NO formation.

The rapid clearance of glucose from the circulation also appears to be crucial for maintenance of endothelial function. Glucose/insulin-mediated vasodilation is impaired during hyperglycaemia: glucose-induced NO release was completely abolished and insulin-induced NO released was reduced after incubation of the PCAs at high glucose concentrations for $2 \mathrm{~h}$. This finding may be explained by accelerated NO degradation due to enhanced superoxide generation in the chronic hyperglycaemic state [43]. However, during the relatively short periods $(\leq 2 \mathrm{~h})$ of incubation with high D-glucose in our experiments, we found no evidence of increased superoxide formation. Alternatively, it has been shown that insulin-induced PI3 K signalling pathways (which mediate endothelial NO release), GLUT4 translocation in skeletal muscle cells and adipocytes, as well as the metabolic actions of insulin, are impaired under conditions of prolonged hyperglycaemia, and are thus considered to constitute the molecular basis of insulin resistance [44, 45]. Additionally, NCX activity was found to be reduced in the high glucose state [46], whereas uptake of glucose by endothelial cells was not affected [47]. This may explain the failure of acute glucose addition to increase NO release after prolonged exposure to high glucose. A previous study demonstrated that improved glycaemic control by insulin infusion therapy partly restored insulin-stimulated endothelial function in patients with type 2 diabetes and ischaemic heart disease, highlighting the detrimental effects of persistent hyperglycaemia on PI3K-dependent signalling [48]. This is consistent with our observation that impaired vasodilatory function was only partly reversed by incubating PCAs previously compromised by high glucose in normoglycaemic buffer. Hence, it appears that the duration of hyperglycaemia determines the vascular response: while acute (post-prandial) hyperglycaemia enhances PI3K-mediated endothelium-dependent vasodilation, persistent hyperglycaemia causes a potentially irreversible impairment of glucose/insulinmediated vasodilation, constituting an early hallmark of glucose- and insulin-resistance.

In summary, this is to our knowledge the first report to describe a D-glucose-stimulated NO release from intact vascular endothelium. We were able to resolve the mechanism for this effect, demonstrating that high extracellular D-glucose activates plasma membrane transporters associated with a net inward flux of $\mathrm{Ca}^{2+}$. Moreover, we found that high D-glucose potentiates the vasodilatory activity of insulin, suggesting that combined glucose- and insulin-mediated endothelial NO stimulation is implicated in the perfusion-dependent acceleration of glucose uptake, which in turn is essential for maintaining vascular endothelial function.

Acknowledgements. We thank K. Helfert for skilful technical assistance. The authors are not aware of any conflict of interest.

\section{References}

1. Johnstone MT, Creager SJ, Scales KM, Cusco JA, Lee BK, Creager MA (1993) Impaired endothelium-dependent vasodilation in patients with insulin-dependent diabetes mellitus. Circulation 88:2510-2516

2. Williams SB, Cusco JA, Roddy MA, Johnstone MT, Creager MA (1996) Impaired nitric oxide-mediated vasodilation in patients with non-insulin-dependent diabetes mellitus. J Am Coll Cardiol 27:567-574

3. Noyman I, Marikovsky M, Sasson S et al. (2002) Hyperglycemia reduces nitric oxide synthase and glycogen synthase activity in endothelial cells. Nitric Oxide 7:187-193

4. Calles-Escandon J, Cipolla M (2001) Diabetes and endothelial dysfunction: a clinical perspective. Endocr Rev 22:36-52

5. Laakso M (1999) Hyperglycemia and cardiovascular disease in type 2 diabetes. Diabetes 48:937-942

6. Haffner SM (1998) The importance of hyperglycemia in the nonfasting state to the development of cardiovascular disease. Endocr Rev 19:583-592

7. Tooke JE, Goh KL (1999) Vascular function in Type 2 diabetes mellitus and pre-diabetes: the case for intrinsic endotheiopathy. Diabet Med 16:710-715

8. Mitrakou A, Kelley D, Mokan M et al. (1992) Role of reduced suppression of glucose production and diminished early insulin release in impaired glucose tolerance. N Engl J Med 326:22-29 
9. Steinberg HO, Brechtel G, Johnson A, Fineberg N, Baron AD (1994) Insulin-mediated skeletal muscle vasodilation is nitric oxide dependent. A novel action of insulin to increase nitric oxide release. J Clin Invest 94:1172-1179

10. Scherrer U, Randin D, Vollenweider P, Vollenweider L, Nicod P (1994) Nitric oxide release accounts for insulin's vascular effects in humans. J Clin Invest 94:2511-2515

11. Williams SB, Goldfine AB, Timimi FK et al. (1998) Acute hyperglycemia attenuates endothelium-dependent vasodilation in humans in vivo. Circulation 97:1695-1701

12. Renaudin C, Michoud E, Rapin JR, Lagarde M, Wiernsperger N (1998) Hyperglycaemia modifies the reaction of microvessels to insulin in rat skeletal muscle. Diabetologia 41:26-33

13. Kawano H, Motoyama T, Hirashima O et al. (1999) Hyperglycemia rapidly suppresses flow-mediated endotheliumdependent vasodilation of brachial artery. J Am Coll Cardiol 34:146-154

14. Title LM, Cummings PM, Giddens K, Nassar BA (2000) Oral glucose loading acutely attenuates endotheliumdependent vasodilation in healthy adults without diabetes: an effect prevented by vitamins C and E. J Am Coll Cardiol 36:2185-2191

15. Beckman JA, Goldfine AB, Gordon MB, Creager MA (2001) Ascorbate restores endothelium-dependent vasodilation impaired by acute hyperglycemia in humans. Circulation 103:1618-1623

16. Kim SH, Park KW, Kim YS et al. (2003) Effects of acute hyperglycemia on endothelium-dependent vasodilation in patients with diabetes mellitus or impaired glucose metabolism. Endothelium 10:65-70

17. Cipolla MJ, Porter JM, Osol G, Mayhan WG (1997) High glucose concentrations dilate cerebral arteries and diminish myogenic tone through an endothelial mechanism. Stroke 28:405-411

18. van Veen S, Frolich M, Chang PC (1999) Acute hyperglycaemia in the forearm induces vasodilation that is not modified by hyperinsulinaemia. J Hum Hypertens 13:263-268

19. Hoffman RP, Hausberg M, Sinkey CA, Anderson EA (1999) Hyperglycemia without hyperinsulinemia produces both sympathetic neural activation and vasodilation in normal humans. J Diabetes Complications 13:17-22

20. Oomen PH, Kant GD, Dullaart RP, Reitsma WD, Smit AJ (2002) Acute hyperglycemia and hyperinsulinemia enhance vasodilatation in Type 1 diabetes mellitus without increasing capillary permeability and inducing endothelial dysfunction. Microvasc Res 63:1-9

21. Houben AJ, Schaper NC, de Haan CH et al. (1996) Local 24-h hyperglycemia does not affect endothelium-dependent or -independent vasoreactivity in humans. Am J Physiol 270:H2014-H2020

22. Brands MW, Fitzgerald SM (1998) Acute endothelium-mediated vasodilation is not impaired at the onset of diabetes. Hypertension 32:541-547

23. Charkoudian N, Vella A, Reed AS et al. (2002) Cutaneous vascular function during acute hyperglycemia in healthy young adults. J Appl Physiol 93:1243-1250

24. Taubert D, Berkels R, Klaus W, Roesen R (2002) Nitric oxide formation and corresponding relaxation of porcine coronary arteries induced by plant phenols: essential structural features. J Cardiovasc Pharmacol 40:701-713

25. Berkels R, Mueller A, Roesen R, Klaus W (1999) Nifedipine and Bay $\mathrm{K} 8644$ induce an increase of $\left[\mathrm{Ca}^{2+}\right]_{\mathrm{i}}$ and nitric oxide in endothelial cells. J Cardiovasc Pharmacol Ther 4:175-181

26. Grynkiewicz G, Poenie M, Tsien RY (1985) A new generation of $\mathrm{Ca}^{2+}$ indicators with greatly improved fluorescence properties. J Biol Chem 260:3440-3450
27. Edgell CJ, McDonald CC, Graham JB (1983) Permanent cell line expressing human factor VIII-related antigen established by hybridization. Proc Natl Acad Sci USA 80:3734-3737

28. Chomczynski P, Sacchi N (1987) Single-step method of RNA isolation by acid guanidinium thiocyanate-phenolchloroform extraction. Anal Biochem 162:156-159

29. Wang X, Reznick S, Li P, Liang W, van Breemen C (2002) $\mathrm{Ca}^{2+}$ removal mechanisms in freshly isolated rabbit aortic endothelial cells. Cell Calcium 31:265-277

30. Bell GI, Burant CF, Takeda J, Gould GW (1993) Structure and function of mammalian facilitative sugar transporters. J Biol Chem 268:19161-19164

31. Wright EM (2001) Renal $\mathrm{Na}^{+}$-glucose cotransporters. Am J Physiol Renal Physiol 280:F10-F18

32. Ohta T, Isselbacher KJ, Rhoads DB (1990) Regulation of glucose transporters in LLC-PK1 cells: effects of D-glucose and monosaccharides. Mol Cell Biol 10:6491-6499

33. Uchida H, Tanaka Y, Ishii K, Nakayama K (1999) 1-type $\mathrm{Ca}^{2+}$ channels are not involved in coronary endothelial $\mathrm{Ca}^{2+}$ influx mechanism responsible for endothelium-dependent relaxation. Res Commun Mol Pathol Pharmacol 104:127-144

34. Teubl M, Groschner K, Kohlwein SD, Mayer B, Schmidt K (1999) $\mathrm{Na}(+) / \mathrm{Ca}(2+)$ exchange facilitates $\mathrm{Ca}^{2+}$-dependent activation of endothelial nitric-oxide synthase. J Biol Chem 274:29529-29535

35. Schneider JC, El Kebir D, Chereau C, Mercier JC, Dall'Ava-Santucci J, Dinh-Xuan AT (2002) Involvement of $\mathrm{Na}^{+} / \mathrm{Ca}^{2+}$ exchanger in endothelial NO production and endothelium-dependent relaxation. Am J Physiol Heart Circ Physiol 283:H837-H844

36. Sedova M, Blatter LA (1999) Dynamic regulation of $\left[\mathrm{Ca}^{2+}\right]_{\mathrm{i}}$ by plasma membrane $\mathrm{Ca}^{2+}$-ATPase and $\mathrm{Na}^{+} / \mathrm{Ca}^{2+}$ exchange during capacitative $\mathrm{Ca}^{2+}$ entry in bovine vascular endothelial cells. Cell Calcium 25:333-343

37. Nishizaki T, Kammesheidt A, Sumikawa K, Asada T, Okada Y (1995) A sodium- and energy-dependent glucose transporter with similarities to SGLT1-2 is expressed in bovine cortical vessels. Neurosci Res 22:13-22

38. Nishizaki T, Matsuoka T, Kammesheidt A, Sumikawa K, Asada T, Okada Y (1998) Low glucose enhances $\mathrm{Na}^{+} /$glucose transport in bovine brain artery endothelial cells. Stroke 29:844-849

39. Sobrevia L, Nadal A, Yudilevich DL, Mann GE (1996) Activation of L-arginine transport (system $\mathrm{y}+$ ) and nitric oxide synthase by elevated glucose and insulin in human endothelial cells. J Physiol 490:775-781

40. Tangphao O, Chalon S, Coulston AM et al. (1999) L-arginine and nitric oxide-related compounds in plasma: comparison of normal and arginine-free diets in a 24-h crossover study. Vasc Med 4:27-32

41. Tangphao O, Grossmann M, Chalon S, Hoffman BB, Blaschke TF (1999) Pharmacokinetics of intravenous and oral L-arginine in normal volunteers. Br J Clin Pharmacol 47:261-266

42. Montagnani M, Chen H, Barr VA, Quon MJ (2001) Insulin-stimulated activation of eNOS is independent of $\mathrm{Ca}^{2+}$ but requires phosphorylation by Akt at Ser(1179). J Biol Chem 276:30392-30398

43. Cosentino F, Hishikawa K, Katusic ZS, Luscher TF (1997) High glucose increases nitric oxide synthase expression and superoxide anion generation in human aortic endothelial cells. Circulation 96:25-28

44. Zierath JR, Krook A, Wallberg-Henriksson H (2000) Insulin action and insulin resistance in human skeletal muscle. Diabetologia 43:821-835

45. Steinberg HO, Baron AD (2002) Vascular function, insulin resistance and fatty acids. Diabetologia 45:623-634 
46. Hattori Y, Matsuda N, Kimura J et al. (2000) Diminished function and expression of the cardiac $\mathrm{Na}^{+}-\mathrm{Ca}^{2+}$ exchanger in diabetic rats: implication in $\mathrm{Ca}^{2+}$ overload. J Physiol 527:85-94

47. Vinals F, Gross A, Testar X, Palacin M, Rosen P, Zorzano A (1999) High glucose concentrations inhibit glucose phosphorylation, but not glucose transport, in human endothelial cells. Biochim Biophys Acta 1450:119-129
48. Rask-Madsen C, Ihlemann N, Krarup T et al. (2001) Insulin therapy improves insulin-stimulated endothelial function in patients with type 2 diabetes and ischemic heart disease. Diabetes 50:2611-2618

49. Poppe R, Karbach U, Gambaryan S et al. (1997) Expression of the $\mathrm{Na}^{+}$-D-glukose cotransporter SGLT1 in neurons. J Neurochem 69:84-94 